\title{
Peningkatan Produktivitas Azolla Sebagai Pakan Ternak Unggas dengan Penggunaan Pupuk Kandang
}

\author{
Santi $^{1 *}$, Andi Tenri Bau Astuti Mahmud ${ }^{2}$, Andi Fausiah ${ }^{3}$, Nursani $^{4}$ \\ 1,2,3Program Studi Peternakan, Fakultas Ilmu Pertanian, Universitas Al Asyariah Mandar \\ ${ }^{4}$ Program Studi Teknologi Hasil Peternakan Fakultas Pertanian dan Peternakan Univesitas Muhammadiyah Bone \\ *Email : santipeternakan@gmail.com
}

\begin{abstract}
Tujuan penelitian ini adalah memperbaiki produktivitas azolla. Penelitian ini dilaksanakan April - Juli 2021. Pemeliharaan azolla dilaksanakan di mini ranch program studi peternakanan Fakultas Ilmu Pertanian Universitas Al Asyariah Mandar. Rancangan yang digunakan dalam penelitian ini adalah rancangan acak lengkap (RAL) non faktorial dengan 5 perlakuan dan 3 ulangan. Unit yang digunakan adalah kolam terpal dengan ukuran $1 \times 1 \times 0,3$ m sebanyak 15 unit kolam Perlakuan $\mathrm{P}_{0}=$ Pupuk kandang asal ayam $100 \%$; Perlakuan $\mathrm{P}_{1}=$ Pupuk kandang asal ayam 75\% + pupuk kandang asal sapi 25\%; Perlakuan $\mathrm{P}_{2}=$ Pupuk kandang asal ayam 50\% + pupuk kandang asal sapi $50 \%$; Perlakuan $\mathrm{P}_{3}=$ Pupuk kandang asal ayam $25 \%+$ pupuk kandang asal sapi $75 \%$; Perlakuan $\mathrm{P}_{4}=$ Pupuk kandang asal sapi $100 \%$. Hasil penelitian yang diperoleh yaitu penggunaan level pupuk kandang yang berbeda berpengaruh nyata $(\mathrm{P}<0.05)$ terhadap berat segar azolla, pertambahan biomassa azolla, dan kadar bahan kering azolla. Produksi yang terbaik tedapat pada perlakuan P0 dengan berat segar $1842.75 \mathrm{~g}$, pertambahan biomassa azolla $1542.75 \mathrm{~g}$, dan kadar bahan kering $20.93 \%$.
\end{abstract}

Keywords : Azolla; Produksi; Pupuk Kandang

\section{Pendahuluan}

Azolla merupakan tumbuhan paku air dan salah satu pakan alami yang melimpah ketersediaannya di alam yang belum termanfaatkan secara optimal, tumbuh dan berkembang dengan cepat, hidupnya mengambang di atas permukaan air serta bersimbiosis dengan Cyanobacteria (alga hijau biru) mampu memfiksasi (N2) nitrogen udara. Azolla microphylla bisa dijadikan salah satu pakan alternatif menguntungkan, biaya yang sangat ekonomis, dan juga sangat digemari oleh ternak unggas. Menurut (Handajani 2011) kadar protein kasar azolla yaitu 13,1 - 39,62 \%. Selanjutnya salam penelitian (Maya et al. 2019) dengan penggunaan azolla segar pada samapai $48 \%$ dapat memperbaiki bobot badan pada ayam broiler, sedangkan (Dewanti 2007) menjeelaskan pemberian tepung azolla pada itik manila afesien pada level $15 \%$.

Nillia nutrisi yang terkandung pada Azolla dipengaruhi oleh unsur hara dari media tumbuhnya. Ketersediaan unsur hara sangat penting dalam dalam proses metabolisme tanaman. Kebutuhan tanaman akan setiap unsur hara tergantung pada ketersediaan dari semua unsur hara yang ada dalam tanah. Pada umumnya hasil ini berkaitan dengan kenyataan bahwa hasil maksimum yang dapat dicapai bila semua kondisi pertumbuhan termasuk penyediaan hara berada dalam kondisi optimal. Hal tersebut dapat dilakukan dengan pemberian unsur hara pada tanaman melalui pemupukan.

Pupuk kandang merupakan sumber energy dan nitrogen bagi mikroorganisme. Pupuk kandang yang banyak tersedia saat ini yaitu pupuk kandang asal ayam dan sapi. Pupuk kandang asal ayam memiliki unsur hara pupuk kandang ayam memiliki kandungan Nitrogen $(\mathrm{N})$ 2,44\%, Phospor (P) 0,67\%, Kalium (K) 1,24\%, dan C-
Organik 16,10\% (Manure et al. 2016). Sedangkan kandungan Kandungan unsur hara pupuk kandang dari kotoran sapi yaitu mempunyai kadar serat yang tinggi seperti selulosa, hal ini terbukti dari hasil pengukuran parameter $\mathrm{C} / \mathrm{N}$ rasio yang cukup tinggi $>40$. Disamping itu pupuk ini juga mengandung unsur hara makro seperti $0,5 \mathrm{~N}, 0,25 \mathrm{P} 2 \mathrm{O} 5,0,5 \% \mathrm{~K} 2 \mathrm{O}$ dengan kadar air 0,5\% (Pranata 2010).

Berdasarkan hal tersebut penelitian ini dilakukan dengan mengkombinasikan pupuk kandang dari kotoran ayam dan kotoran sapi. Tujuan penelitian ini adalah memperbaiki produktivitas azolla. Dengan demikian kebutuhan pakan untuk unggas, khususnya kebutuhan protein dapat terpenuhi baik secara kualitas maupun kuantitas.

\section{Metodologi}

\section{Tempat dan Waktu Penelitian}

Penelitian ini dilaksanakan April - Juli 2021. Pemeliharaan azolla dilaksanakan di mini ranch program studi peternakanan Fakultas Ilmu Pertanian Universitas Al Asyariah Mandar.

\section{Materi}

Alat yang digunakan yaitu kolam terpal, tali rapiah, Patok kayu, bamboo, timbangan, dan pisau, Bahan yang digunakan yaitu azolla segar, air, pupuk kandang dari ayam dan pupuk kandang dari sapi, lumpur mineral, dan bahan analisis proksimat.

\section{Rancangan Penelitian}

Rancangan yang digunakan dalam penelitian ini adalah rancangan acak lengkap (RAL) non faktorial dengan 5 perlakuan dan 3 ulangan. Unit yang digunakan 
adalah kolam terpal dengan ukuran $1 \times 1 \times 0,3$ m sebanyak 15 unit kolam. Media tumbuh yang digunakan adalah kombinasi antara pupuk kandang asal ayam dengan pupuk kandang asal sapi, dengan penggunaan pupuk 300 gram di setiap kolamnya. Sesuai dengan (Surdina, Elrahimi, and Hasri 2016) apabila Azolla sp. di produksi secara terus menerus, maka diperlukan 200-400 g/m2 pupuk.

Penelitian ini secara keseluruhan menghasilkan 15 kombinasi perlakuan, yaitu $5 \times 3$ unit percobaan dengan perlakuan sebgai berikut:

Perlakuan $\mathrm{P}_{0}=$ Pupuk kandang asal ayam $100 \%$.

Perlakuan $\mathrm{P}_{1}=$ Pupuk kandang asal ayam $75 \%+$ pupuk kandang asal sapi $25 \%$.

Perlakuan $\mathrm{P}_{2}=$ Pupuk kandang asal ayam $50 \%+$ pupuk kandang asal sapi $50 \%$.

Perlakuan $\mathrm{P}_{3}=$ Pupuk kandang asal ayam $25 \%+$ pupuk kandang asal sapi $75 \%$.

Perlakuan $\mathrm{P}_{4}=$ Pupuk kandang asal sapi $100 \%$

\section{Prosedur Penelitian}

Kolam yang digunakan pada penelitian ini adalah kolam terpal dengan ukuran kolam $1 \times 1 \times 0,3$ m sebanyak 15 kolam. Bagian atas kolam digunakan paranet yang berfungsi untuk melindungi Azolla yang di dalam kolam dari sinar cahaya matahari secara langsung, paranet yang digunakan berukuran $18 \times 9 \mathrm{~m}$. Pada bagian dasar kolam ditambahkan tanah lumpur dengan ketebalan $5 \mathrm{~cm}$ perkolamnya. Pupuk yang akan digunakan dihaluskan terlebih dahulu hingga menjadi butiran-butiran halus. kemudian pupuk tersebut dicampurkan dengan substrat tanah lumpur yang di dalam kolam sesuai dengan perlakuan masing-masing. Air dimasukkan sebanyak 10 $\mathrm{cm}$ ke setiap kolam. Kemudian kolam didiamkan selama 3 hari agar air, substrat tanah lumpur dan pupuk bisa tercampur secara homogen. Azolla ditebar pada pagi hari.

Bibit azolla ditebar diarea kolam uji sebanyak 300 gram/kolam setiap perlakuannya. Pengambilan data untuk perkembangan biomassa Azolla dilakukan penimbangan bobot segar pada hari pertama dan hari ke 35.

\section{Parameter Penelitian}

\section{Berat Basah Akhir}

Azollla segar yang baru dipanen pada umur 35 hari ditiriskan beberapa menit setelah itu ditimbang.

Pertambahan Biaomassa Berat Basah Azolla

Perhitungan bobot biomassa segar Azolla dilakukan pada saat pemanenan dengan cara Azolla yang sudah dipanen kemudian ditiriskan bertujuan untuk mengurangi kadar air yang menempel pada tanaman Azolla dan ditimbang, hasil biomassa akhir dikurangi dengan biomassa awal.

\section{Analisis Bahan Kering}

Analisa bahan kering tanaman Azolla yaitu sampel di oven selama 3 ja dengan suhu $105^{\circ} \mathrm{C}$.

\section{Hasil}

Produktivitas tanaan azolla dapat dilihat dari pertabahan biomassanya dan untuk kualitas dapat diukur dari kadar bahan kering. Tinggi rendahnya produktivitas tanaan azolla sangat dipengaruhi dari media tumbuh. Pada penelitian ini, nilai rataan pertambahan biomassa dan kadar bahan kering disajikan pada tabel 1.

Tabel 1. Berat azPertambahan Biomassa dan Kadar Bahan Kering Azolla yang menggunakan pupuk kandang dari feses ayam dan feses sapi

\begin{tabular}{lccl}
\hline \multirow{3}{*}{ Perlakuan } & \multicolumn{3}{l}{ Parameter } \\
\cline { 2 - 4 } & $\begin{array}{l}\text { Berat } \\
\text { Segar }(\mathrm{g})\end{array}$ & $\begin{array}{c}\text { Pertambahan } \\
\text { biomassa }(\mathrm{g})\end{array}$ & Bahan kering $(\%)$ \\
\hline \multirow{4}{*}{ P0 } & $1842.75^{\mathrm{a}}$ & $\pm 1542.75^{\mathrm{a}}$ & \pm \\
& 52.03 & 52.29 & $20.93^{\mathrm{a}} \pm 1.85$ \\
P1 & $1691.85^{\mathrm{b}} \pm$ & \pm & \\
& 7.78 & $1391.85^{\mathrm{b}} \pm 7.78$ & $19.21^{\mathrm{ab}} \pm 0.57$ \\
P2 & $1601.93^{\mathrm{a}}$ & \pm & \\
& 3.18 & $1301.93^{\mathrm{c}} \pm 3.18$ & $18.47^{\mathrm{bc}} \pm 0.42$ \\
P3 & $1314.24^{\mathrm{d}} \pm$ & \pm & \\
& 21.54 & $1014.24^{\mathrm{d}} \pm 21.54$ & $17.70^{\mathrm{bc}} \pm 0.32$ \\
P4 & $1119.07^{\mathrm{e}} \pm$ & $\pm 197^{\mathrm{e}} \pm 48.87$ & $16.97^{\mathrm{c}} \pm 0.88$
\end{tabular}

Keterangan: Huruf yang Berbeda pada Superscript Angka RataRata, Berbeda Nyata $(\mathrm{P}<0.05)$, Perlakuan $\mathrm{P}_{0}=$ Pupuk kandang asal ayam $100 \%$. Perlakuan $\mathrm{P}_{1}=$ Pupuk kandang asal ayam $75 \%+$ pupuk kandang asal sapi $25 \%$. Perlakuan $\mathrm{P}_{2}=$ Pupuk kandang asal ayam 50\% + pupuk kandang asal sapi 50\%. Perlakuan $\mathrm{P}_{3}=$ Pupuk kandang asal ayam $25 \%+$ pupuk kandang asal sapi $75 \%$. Perlakuan $\mathrm{P}_{4}=$ Pupuk kandang asal sapi $100 \%$

Tanaman Azolla memiliki produksi yang tinggi dengan pertumbuhan yang sanagat cepat sehingga memilki potensi dijadikan pakan unggas. Penelitian ini menunjukkan bahwa level penggunaan pupuk kandang dari feses ayam dan sapi berpengaruh nyata $(\mathrm{P}<0.05)$ terhadap berat segar, pertambahan biomassa dan kadar bahan kering azolla.

Berat segar azolla mengalami cenderung penurunan dengan penambahan level pupuk kandang sapi dibandingkan dengan yang diberi pupuk kandang feses ayam, hal tersebut dapat dilihat pada gambar 1 .

Berat segar azolla pada perlakuan P0, P1, P2, P3 dan P4 menunjukkan perbedaan yang nyata. Perbedaan tersebut terjadi karena penggunaan level pupuk kandang yang berbeda. Berat basah azollah yang tertinggi terdapat pad perlakuan P0 dengan penggunaan pupuk kandang dari feses ayam $100 \%$ dan terendah pada perlakuan P4 dengan perlakauan $100 \%$ feses sapi.

Level penggunaan pupuk kandang dari feses ayam memilki korelasi positif dengan produksi berat segar azolla. Hal tersebut disebabkan pupuk kandang dari feses ayam memiliki kadar nitrogen yang tinggi dibandingkan dengan feses sapi. (Kusuma 2015)yang menyatakan bahwa kebutuhan akan unsur hara $\mathrm{N}$ yang terdapat pada kotoran ayam pada tanaman tercukupi selama pertumbuhannya, apabila kebutuhan unsur $\mathrm{N}$ tercukupi maka akan meningkatkan pertumbuhan tanaman dan jumlah anakan juga semakin banyak. 


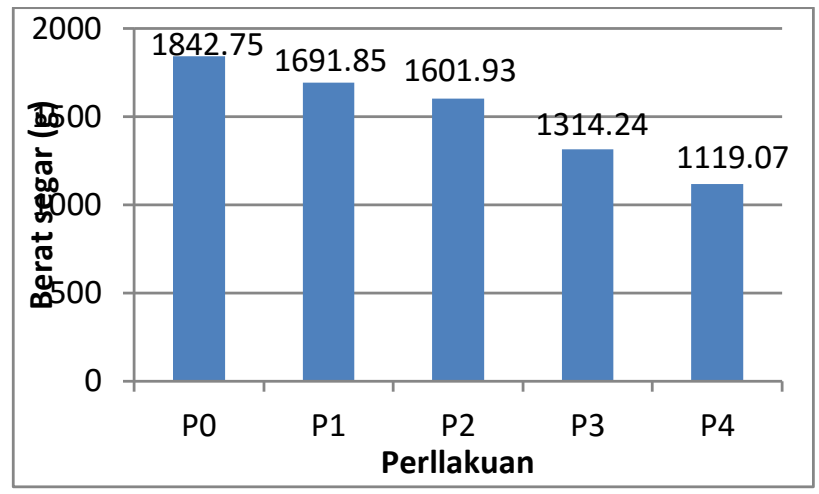

Gambar 1. Berat segar azolla dengan penggunaan pupuk kadang dari feses ayam dan feses sapi

Semakin tinggi level penggunaan pupuk kandang dari feses sapi pertambahan biomassa semakin turun . Hal tersebut dapat dilihat dari hasil uji Duncan yaitu perlakuan P0 nyata lebih besar dengan P, P2, P3, dan P4. Perlakuan P1 nyata lebih besar dari P2, P3, dan P4. Perlakuan P3 nyata lebih tinggi dari P4.

Pertambahan biomassa azolla berkorelasi positif dengang level penggunaa pupuk kandang dari feses ayam atau berkorelasi negative dengan level penggunaan pupuk kadang dari sapi dapat dilihat pada Gambar 2. Hal tersebut disebabkan dengan kandungan $\mathrm{N}$ pada feses ayam lebih tinggi dibandingkan dengan kandungan $\mathrm{N}$. Sesuai dengan (Pangaribuan, Yasir, and Utami 1970) Pupuk kandang yang berasal dari kotoran ayam memberikan hasil yang lebih tinggi, hal ini berkaitan dengan kemampuan bahan organik pupuk kandang asal ayam dalam memperbaiki sifat biologi tanah. Selain itu bahan organik pupuk kandang asal ayam dapat mensuplai unsur hara terutama unsur hara $\mathrm{N}$, P, dan $\mathrm{K}$ lebih banyak dari pada pupuk kotoran hewan lainnya, unsur-unsur inilah yang dibutuhkan Azolla sp. untuk pertumbuhannya.

Kenyataan ini menunjukkan bahwa tanaman Azolla microphylla mempunyai respon yang tinggi terhadap nutrisi yang dilepaskan oleh pupuk kandang asal ayam. Dalam pupuk kandang asal ayam mengandung unsur fosfat yang yang lebih tinggi dari pada pupuk kandang asal kuda sehingga media tanam yang diperkaya dengan unsur fosfat cenderung meningkatkan produktivitas tanaman Azolla microphylla dan aktivitas penambatan nitrogen oleh Anabaena azollae sangat mempengaruhu pertumbuhan tanaman Azolla sp. karena nitrogen hasil fiksasi akan didistribusikan ke sel azolla yang selanjutnya akan digunakan untuk pertumbuhan tanaman Azolla sp (Surdina et al. 2016).

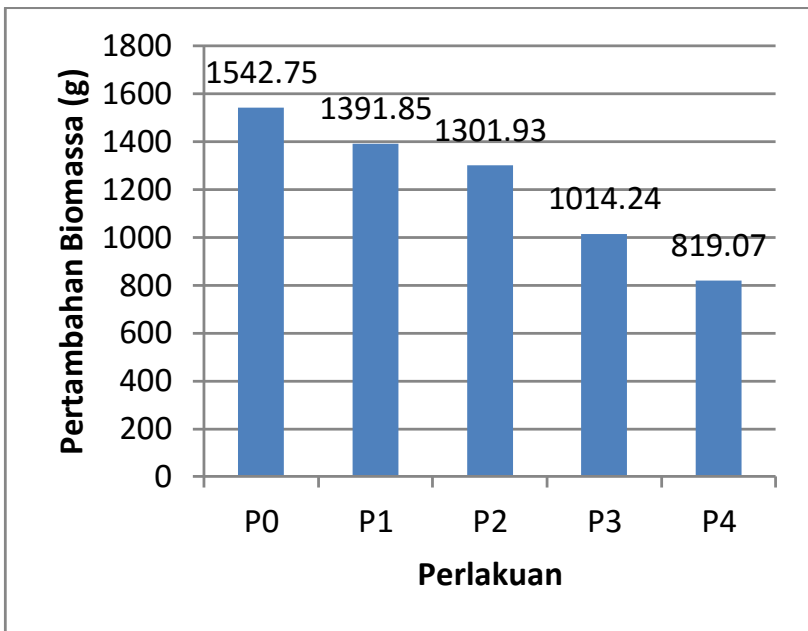

Gambar 2. Pertambahan biomassa azolla dengan penggunaan pupuk kadang dari feses ayam dan feses sapi

Pertambahan biomassa pada azolla memperoleh hasil tertinggi pada perlakuan P0 yang medianya yaitu pupuk kandang dari feses ayam 100\%. Produksi pertambahan biomassa pada perlakuan P0 yaitu $1542.75 \mathrm{~g}$ yang signifikan lebih tinggi dibandingkan perlakuan yang lain. Hal tersebut sesuai dengan (Sunaryo 2020) pupuk kandang yang berasal dari kotoran ayam memberikan hasil yang lebih tinggi, hal ini berkaitan dengan kemampuan bahan organik pupuk kotoran ayam dalam memperbaiki sifat biologi tanah sehingga tercipta lingkungan yang lebih baik bagi perakaran tanaman. Selain itu bahan organik pupuk kotoran ayam dapat mensuplai unsur hara terutama unsur hara $\mathrm{N}, \mathrm{P}$ dan $\mathrm{K}$ lebih banyak dari pada pupuk yang berasal dari ternak besar seperti sapi, kambing, dan kuda. Semua unsur makro tersebut memegang peranan penting dalam metabolisme tanaman. Kenyataan ini menunjukkan bahwa Azolla microphylla mempunyai respon yang tinggi terhadap nutrisi yang dilepaskan oleh pupuk kotoran ayam.

Produktivitas azolla dapat diukur dari kuanitasas (biomassa) dan kualitas (bahan kering). Biomassa tanama tidak selamanya berkorelasi positif. Pada penelitian ini menunjukkan bahwa penggunaan pupuk kandang dari feses ayam dan feses sapi berpengaruh nyata $(\mathrm{P}<0.05)$ terhadap bahan kering azolla.

Hasil uji Duncan menunjukkan perlakuan P0 tidak berbeda nyata dengan $\mathrm{P} 1$, tetapi tidak berbeda nyata dengan P2, P3 dan P4. Perlakuan P1 tidak berbeda nyata P2 dan P3. Sedangkan P2, P3 dan P4 tidak berbeda nyata. Salah satu factor yang mempengaruhi kadar bahan kering pada tanaman termasuk azolla yaitu kandungan unsur hara pada tanah. (Anwar, Karno, and Sumarsono 2003) pupuk organik dapat meningkatkan ketersediaan nitrogen tanah sehingga serapan nitrogen juga meningkat, dan pada sisi lain pupuk organik juga memperbaiki sifat fisik dan kimia tanah sehingga dapat mengatasi kondisi salinitas tanah. 


\section{Kesimpulan}

Berdasarkan hasil dan pembahasan tersebut dapat disimpulkan perlakuan menghasilkan produksi yang maksimal yaitu pada P0 dengan berat segar $1842.75 \mathrm{~g}$, pertambahan biomassa azolla $1542.75 \mathrm{~g}$, dan kadar bahan kering $20.93 \%$.

\section{Daftar Pustaka}

Anwar, S., F. Karno, and Sumarsono. 2003. "Seleksi Toleransi Tanaman Rumput Pakan Terhadap Cekaman Salinitas." $J$. Pengemb. Pet. Trop 347-51.

Dewanti, R. 2007. "Potensi Nutrisi Tepung Azolla Microphylla Dalam Memperbaiki Performan Itik Manila ( Cairina Moschata)." 5(September):12-17.

Handajani, Hany. 2011. "Optimatin of Nitrogen and Phosphorus in Azolla Growth As Biofertilizer." Makara, Teknology 15(2):142-46.

Kusuma, M. E. 2015. "Pengaruh Dosis Pupuk Kotoran Ternak Ayam Terhadap Pertumbuhan Dan Produksi Rumput Brachiaria Humidicola Pada Pemotongan Pertama." Jurnal Ilmu Hewani Tropika (Journal of ... 4(1).

Manure, Poultry, Effect On, Plant Growth, Yield Of Cabbage, and Oxic Dystrudepts Lembantongoa. 2016. "Pengaruh Pupuk Kandang Ayam Terhadap Pertumbuhan Dan Hasil Tanaman Kubis Bunga." 4(April):151-59.

Maya, Desriana, Sari Tarigan, Doni Sahat, and Tua Manalu. 2019. "Fresh Azolla Pinnata as Alternative Feed to Reduce Broiler Production Cost." Jurnal AGRISEP 18(1):177-86.

Pangaribuan, Darwin Habinsaran, Muhammad Yasir, and Novisha Kurnia Utami. 1970. "Dampak Bokashi Kotoran Ternak Dalam Pengurangan Pemakaian Pupuk Anorganik Pada Budidaya Tanaman Tomat." Jurnal Agronomi Indonesia (Indonesian Journal of Agronomy) 40(3):204-10.

Pranata, A. 2010. Meningkatkan Hasil Panen Dengan Pupuk Organik. Jakarta: PT. Agromedia Pustaka.

Sunaryo, Deni. 2020. “Optimalisasi Pemanfaatan Tumbuhan Azzola (Azolla Pinnata) Sebagai Pemberdayaan Sumber Pendapatan Masyarakat Penerima Bantuan Langsung Tunai Yang Terdampak Covid-19 Di Desa Sukaratu Kecamatan Cikeusal Kabupaten Serang." Humanism: Jurnal Pengabdian Masyarakat 1(2):71-80.

Surdina, Eva, Sayyid Afdhal El-rahimi, and Iwan Hasri. 2016. "Pertumbuhan Azolla Microphylla Dengan Kombinasi Pupuk Kotoran Ternak." Jurnal Ilmiah Mahasiswa Kelautan Dan Perikanan Unsyiah 1(November):298-306. 